\title{
"Internet+" and Growth of Farmer's Household Operating Income
}

\author{
Juan Zhang* \\ Nantong University, China
}

Submission: January 15, 2017; Published: February 06, 2017

"Corresponding author: Juan Zhang, Business School of Nantong University, Chong chuan District, Nantong, Jiangsu, 226019, China, Tel: +86 13962730656; Email: nt590590@126.com

\section{Abstract}

In the past two years, it is difficult for farmers to increase income, and the proportion of operating income of farmers has decreased year by year. The "Internet +" action plan is becoming an engine of economic development, also bringing farmers' operating income growth. Before production, farmers can gain more and accurate demand information from markets for production decisions. In the production, farmers more focus on outsourcing, the quality of agro-products. Ultimately it meets consumer's demand, enhances farmers' market position, and increases farmer's household operating income. The growth of operating income comes from the connection dividend in agricultural production and consumption; scale effects by the specialization; return increasing from knowledge combination; the expansion of the value space of agroproducts and the decline of cost. Promoting "Internet+" in China has practical significance to increase farmer's household operating income.

Keywords: The "Internet+"; Farmer's household operating income; Connection dividend

\section{Introduction}

The Internet, firstly appeared in 1969 , has now evolved into a global industry revolution from the initial technology revolution, and is promoting the transformation and upgrade after nearly 50 years of development in the United States. Internet brings the profound change to the Chinese economic development, is implanting to agriculture from accessing 20 years ago. The Internet can updates organization's mental, and reconstruct traditional industry to the real economy is organization [1]. It can make the enterprise achieve precise prediction and prospective development [2]. Companies will have the ability to "connect all" and "connection dividend" [3]. The "Internet + " is a special term, refers to the combination of the Internet with a traditional industry. The concept of "Internet +", can be traced back to November 6, 2013. Ma Huateng said in the opening ceremony of Zhongan Insurance Company what the Internet with a traditional industry represent is a kind of ability, or an external resources and the environment, a promotion of the industry. Chinese Prime Minister Lifirstly put forward the "Internet +" action plan in the $12^{\text {th }}$ National People's Congress meeting. The "Internet +" has become the new engine of economic development and innovation.

There is a difference between "Internet +"and "the Internet". The Internet is a resource, only can be used to improve marketing and production efficiency, the "Internet +" is not only resources, but also can improve enterprise competitive ability [4]. Agricultural production, consumption are moving towards "Internet +" model; gradually take a high speed ride. The research on "Internet + ", mainly concentrated on industrial and financial industry, some less for agriculture. "Internet + agriculture" is the crossover of agriculture and the mobile Internet, big data, cloud computing, and Internet of things, a new products, new model and new formats [5], which has more exploration in practice."Internet + agriculture" has three kinds of patterns and eight paths in Jiangsu [6]. Internet + agricultural lack of talents, and infrastructure is in deficiencies in Shanghai [7]. Farmers' income growth is an old topic, which is related with agricultural development, rural stability in China. In the past two years growth of the farmers' income was sluggish, the proportion of household operating income has been declining. The vision proposed in the party's 18thdescribed that GDP and average income of urban and rural residents would be double in 2020 than 2010. The Basic Modernization Index System in Jiangsu (revised in 2013, trial) determined average income of farmers in entire province would reach 32000 Yuan in 2020. The paper studies "Internet +agriculture" to increase farmers' income, especially for household operating income. It will have a guiding significance to solve the problem of sluggish growth, achieve the intended target. 


\section{Growth of Farmers' Household Operating Income is Difficult at Present}

The farmers' income is the sum of four parts which is from various income accordingly deducting costs. Per capita income of farmers reflects average income level in a region or in a family according to population. The farmers' income in this article refers to the per capita net income which has four aspects in a farmer household, operating, wage, property and transferred income. Farmers' income has been increased from 1995 to 2014 (Figure 1), 1578 Yuan in1995, 9892 Yuan in 2014, the average annual growth of around 10\%, exceeding ten thousand in 2015. In real terms $(1985$ = 100), it was 541 Yuan in 1995, 2160 Yuan in 2014, the average annual growth of $7.5 \%$. Farmers' household operating and wage income were the main part, whose percentage accounted for more than $95 \%$ in 2013.

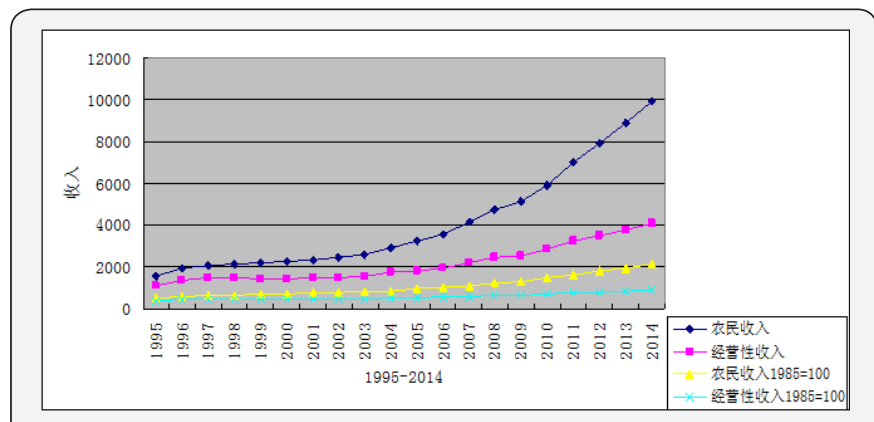

Figure 1: Farmer's Income and Household Operating Income in 1995-2014.

In recent years, China's economy is coming into the "New Normal", and growth ration decreasing. This is directly lead in aggregate demand and revenue to the low growth ratio, will inevitably reduce growth in demand for agro-products, and directly decrease the growth of farmers' income, especially in wage income.

The property income refers to get income in return for providing capital for other institutional units or tangible nonproductive assets. Farmers have land (contracted land, houses) and collective assets, etc. which can liquidate the property. The analysis from Ministry of Land and Resources thought that half of the most expensive constructive land on the market is in the countryside, it is a huge amount. Farmers' residential and rural homesteads still sit idle. If there is a market, it can let farmers' real estate value.

The proportion Farmers' per capita property income is only single digits, accounting for 3.8\%in 2013. Data showed that U.S. residents property income which accounted for about $40 \%$ in 2013 [8]. This paper argues that appreciation potential of the farmers' property income is tremendous. The transferred income refers to all kinds of transfer payment and income transfer between households. Its growth depends on other organizations.

Few years ago the state gave grain, seed, machinery subsidies, improvement of land requisition compensation and so on, which increased farmers' transferred income. But nearly farmers are not given more the transferred income, the growth ratio is slow. The property and transferred income are affected by policies, which have little relation with the paper. So the paper will put aside it below.

\section{The Proportion of Farmers' Household Operating Income is Decreasing}

The farmers' household operating income means income which is the result of combination of land and other factors, is one of the four components. It includes income that some unclaimed licensed farmers are engaged in cottage industry in China statistics. Objectively, weak agricultural industry, less rural incomes channels constraint the growth of farmers' income. The percentage of the farmers' household operating income is decreasing by deconstructing the farmers' income components. (Figure 2) is the proportion of farmers' household operating income in 1995-2014, in which the proportion accounted for a declining trend in 1995$2014,71.36 \%$ in $1995,53.83 \%$ in 2006 , and $41.34 \%$ in 2014 ; fell by nearly $30 \%$ within 20 years. Farmers' wage income started to exceed operating income in 2013, became the largest part of the farmers' income. The percentage of wage income increases rapidly, while confirming sluggish growth in farmers' household operating income relatively.

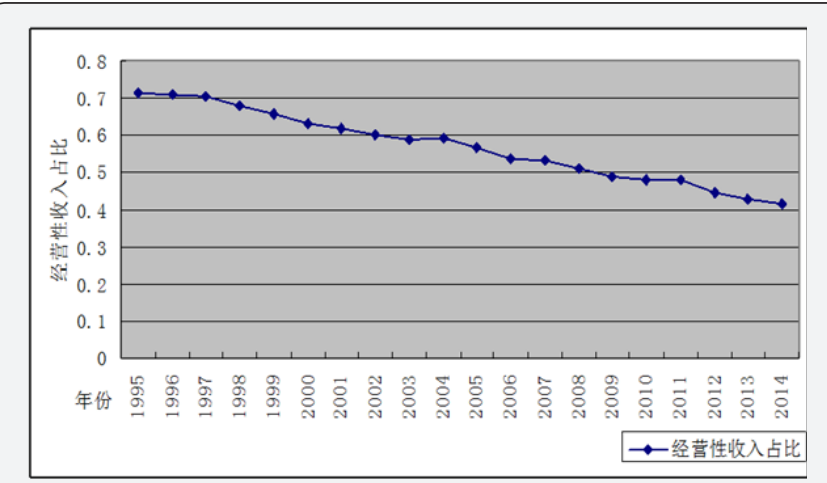

Figure 2: The proportions of Farmers' Household Operating Income in 1995-2014.

\section{The Reasons for the Declining Proportion of Household Operating Income}

The household operating income is a result of quantity of agro-production, land area, price level. Growth of agro-production output, planting area and price can bring income increment. In a normal year agro-product yield is basic stable; it is difficult to have a substantial growth. Multiple Crop Index, cropping system, as a culture, it is hard to be changed in a short time.

In a normal year, output is stable. With the constant improvement of the industrialization and urbanization, arable land reduction is inevitable by drawing on the experience of the developed countries abroad. In recent years Chinese the urbanization process is accelerated, the cultivated land is also reducing. Agricultural planting area also decreases. The price of agro-products has been rising; its ratio has been faster than other products, but agricultural 
means of production rising too. To some extent, it has been offset the growth. Cottage industry in China usually is on a smaller scale, the low level of technology, lack of market information, poor ability to survive. In the New-normal, this part income growth is very difficult. In this paper, the farmers' income is the amount per capita one. In recent years population of farmers has decreased in statistics. It contributes to increase farmers' household income generally.

\section{The "Internet +" Changes Farmers' Cultivation Behavior}

According to the Theory of Schultz's, in the process of transition from traditional agriculture to modern agriculture, agriculture must be introduced new modern agricultural production factors to improve agricultural investment yields. At present Chinese agriculture is in transition, the "Internet + " is the engine of the transformation and upgrading, which is an important force in promoting the farmers' income.

\section{The Situation of "Internet +agriculture" in Chinese Rural}

The rapid development of Internet, the New-farmers and the rise of e-commerce is bringing the opportunity to the "Internet + agriculture".

\section{The internet development is very fast in chinese rural}

China Internet Information Centre (CNNIC) surveyed China's mobile Internet that as of December 2015, 688 million Internet users in China, the Internet penetration rate reached $50.3 \%$, half of the Chinese people have access to the Internet, and mobile Internet users accounted for more than ninety percent. As of December 2014 , our rural scale up to 178 million people, accounting for $28.6 \%$ of all Internet users, compared with an increase of 2013.

In all kinds of Internet terminals, the rural areas the proportion of Internet users use mobile Internet was $84.6 \%$ in 2014, and 5\% higher than that in cities and towns. The Internet promotion and application in the rural areas, is serving the farmer's production and living, also promoting the development of the "Internet + agriculture".

\section{The new-farmers continue to spring out}

The New-farmers refer to farmers who are engaged in agricultural production, circulation, service using the Internet as a tool, its core is "Internet + agriculture". This is different with new types of agricultural operating main body (family farms, farmers' professional cooperatives, agricultural leading enterprises) which was named in the $3^{\text {rd }}$ Plenary Session of the $18^{\text {th }}$. In 2014, Alibaba and China Post, etc. began to implement the strategy of the "Internet + agriculture". 2015 was the first "New-farmers' year. With the continuous improvement of network communication infrastructure and the use of the intelligent mobile terminal, the New-farmers reach millions in 2015, such as "young prince dishes" with semifinished raw vegetables, Liu Tao Rural Extension and Cloud farm of Legend and so on.

E-commerce of agro-products is emerging: E-commerce of agro-products is a kind of direct-sale model of production and marketing docking, namely F2F, 020. E-commerce has 3 models which are rising. One is the agricultural e-commerce platform, such as Jingdong and No. 1 Shop. According to varieties, brands, producing areas, they searched for all kinds of agro-products to sale on the Internet. This kind of e-commerce platform is largely an agro-product online market in the region.

The second are comprehensive platforms; which integrate agroproduct sales and technology extension, while monitoring product capacity, extending standardized technique, tracking product quality, such as Caiyitong in Chengdu, Jiayuan Net in Jiangsu. The third is the platforms for extension and exhibition. This shows agricultural materials, both at home and abroad product pictures, videos on-site. Farmers can learn the application according to the video demonstration by Internet surfing. The e-commerce platform is a production and marketing docking, is no longer the traditional channel like "manufacturer-wholesaler- consumers". Marketing place is no longer a king.

The "Internet +agriculture" is changing farmers' cultivation behavior Farmers can gain more and accurate information for decision-making, even can directly touch the consumption demand, outsource their cultivation, and optimize investment behaviors.

Farmers can gain more and accurate information. Information for agriculture cultivating has been lagged behind. Farmers' planting and decision relied on intuition or information of previous season, but which was outdated. The phenomenon was relatively common, like"rush, a coax down", and "a bottle of water is more expensive than a bottle of oil", brought loss to farmers. Under the market-oriented, governments at all levels are often difficult to effectively prevent this from happening. Mobile Internet can predict in advance by processing large volume data and application in realtime [4]. The "big data + calculation=big business opportunities [8]. Through the use of agricultural big data, cloud computing analysis, forecast, the governments can also transmit the information in a timely manner to farmers. Farmers can make decision earlier and take action in time, after getting the exact information. Large agricultural leading enterprises and other new types of agricultural main bodies can guide planting from the market information, like the differentiation on the customer's demand. It breaks the barriers of information asymmetry, brings variation in the rationality of structure and process, which originally rely on traditional business value, and creates value in chain of sales, production, and customers. Multiply information optimizes farmer' decision-making.

\section{Farmers can touch the market demand directly}

Distribution was once one of the important components of business models. The help of other distribution channels or distributors system were tools for traditional creating value [9]. "Channels were a king". Traditional agro-products marketing channels were that brokers through enter into agro-product wholesale market by the logistics, vendors went to the wholesale market and then to consumers. Agro-product middlemen or even a few middlemen separated consumers from producers. 
The disintermediation of the Internet can have direct interaction between agricultural production, consumption, and market awareness [4]. Both sides of supply and demand can have direct interaction, with no help of channels, for example, 020. Consumers experience a farm through offline, purchase for online, or buy online after looking for assessment from other buyers; or buy online by online consultation. This doesn't need agent(s), wholesale markets. The Internet contributes to the realization of the trading behavior between supply and demand. Farmers can directly touch consumer's demand. In this kind of direct interaction, shared value emotion and trust between production and marketing, between the communities is produced. It reinforces the affection, enhancing the customers' loyalty.

\section{Farmers use more outsourcing}

Production is a heavy manual labor such as seeding, planting, plant protection, water management, harvesting Etc. In Chinese rural, young and strong labors are rare, who are working in the towns or cities. Most of farmer household tend to outsource planting service. Under the "Internet +agriculture", they make their community platforms to get the real performances of the outsourcing, sharing their experiences and reduce dependence on the servicer's information and seeking balance between different servicers. It also let transferring labors reduce transportation and information cost, and pays more attention on their work. The server's price is cheap with professional works. Outsourcing scale reaches 75\% of total area in Nantong, Jiangsu, 2015.

\section{Investment behaviors are changing}

Large outsourcing servicers need more agricultural machinery. Outsourcing servicers search agricultural machinery online, comparing price, which reduce information asymmetry, and change purchasing model from past "personal combat group" to "consumption group against the production ". Agricultural machinery has strong specificity, such as high investment and sunk costs, the short using period, long payback period. Farmers have no much money to buy the machinery, their house, contracted land etc. cannot be mortgaged, they do not gain loan easily. They tend to lease agricultural machinery to provide outsourcing service. They arrange service schedules under planning as whole and put it online that can ensure not to delay the season. The servicers provide outsourcing service in different place according to the season, enlarging service scale can reduce cost and price, too.

\section{Farmers pay attention to the quality of agro-products}

Issues about agro-product quality over the years have been widespread concern of society. Along with the development of "the Internet", especially the Internet of things, consumers with the Internet can supervise the agricultural production whose traceability system gradually reverse farmers to pay attention on the quality of agro-product. Mengniu is using Baidu Cloud technology and QR code trace ability system to trace milk quality. Iiayuan net in Jiangsu Province, cooperate with off-price stores, distribution enterprise, carry out "gathering to plant in upstream, gathering to sale in downstream, docking platform "for the high quality vegetables etc.

\section{The "Internet +agriculture" is Changing Demand}

\section{Consumer demand can be satisfied fully}

Agro-product market is close to perfect competition market. Agricultural production, especially in agricultural commodity production has a strong homogeneity, is basically a low cost to meet the needs of the masses. With the development of economy, the demand for agro-products will present personalization. Many varieties, small batch, fast renovation of personalized demand continue to pressure on agriculture and agricultural production system, push supply transformation to demand flexibility system, like C2B. This is the "long tail" driven business model. Under the pull of market demand, and supply behavior will change gradually to meet the personalized needs, expand the value of space. Personalized requirements, match the Chinese farmers small planting scale.

\section{Bargaining power of consumers is surging}

The Internet is mainly information products, and it is easy to outdate, whose life cycle is often very short. So the consumer demand for the Internet products is often with real-time [4]. Consumers can see the whole process by the videos, pictures, pastures, factory production through network; determining the quality of state by experiences and related data. They also share and keep the information timely in the consumer community platforms, ensuring the quality and safety of agricultural products' consumption, reducing dependence on farmers' information. Agroproducts have strong homogeneity characteristics, the consumers search different manufacturer information to reduce conversion and distributor of cost between ago-product manufacturers, realizing balances. Market bargaining power of consumers is surging.

The sources of the growth of farmers' household income of "Internet+agriculture" The "Internet+" deconstructs value chain of agricultural industry, restructuring agricultural sectors, and connecting with the "Internet+"seamlessly, realizing value creation and save costs. This is an innovation to the Value Chain Theory, with the improvement of social welfare.

The connection of production and consumption with outside produces dividend. The Internet emphasizes on their own value creation by rearranging and integrating, and brings new products, new services and new business models based on the original industry $[10,11]$. In agricultural input, for example, farmers need chemical fertilizers, seeds, film marketing information in time through the "Internet +", and choose the highest rated products to avoid fake causing losses in the community feedback. In planting, plant protection or harvest sectors, farmers choose outsourcing services, getting Penrose rents.

Family farms and other large agricultural main bodies integrate and configure resources, produce Ricardian rents. Of the Value Chain Theory, "Internet +" deconstruct the agricultural industry value 
chain, and with which restructure other industry chain seamlessly to realize the value creation and cost savings. Connection-dividend pioneered the Internet age, driving all of the enterprises to change the original business model, and, so to speak, connect bonus the dividend is the source of the Internet business model [4].

\section{Specialization Produces Economies of Scale}

Specialization makes industry more and more sophisticated, meanwhile having opportunism, whose cost offsets traditional production of increasing returns that is from specialization. But the Internet reduces the information asymmetry, and then inhibits opportunism. The "Internet +" interacts with bodies of agricultural production in the virtual space platform, expanding the production scale, increasing scale-effect, and reducing costs. And the cost of super large scale is decreased too, because of the information symmetry. In planting, the tractor drivers control each planting of demand information via the Internet, planning overall, letting the mechanicals operate continuously, reducing the search time, expanding the service area, and producing scale return. Further according to the season, they provide service in different areas to expand areas. Agricultural production operation is subject to Young- Smith Theorem, rather than Smith's Theorem in traditional economic era.

Knowledge combination brings the increasing return. A lot of supply and demand entity communicates in the virtual space platforms, gathering knowledge and information, sharing diversified knowledge and information, realizing the increasing return. Knowledge and information accumulation, combination, and sharing, compensate for farmers who lack of knowledge, information. Agriculture has a very strong externality.

All kinds of knowledge, technology and information which are from virtual platform, spreads easily among the farmers, especially those who are able to benefit farmers. The increasing return of knowledge far outweighs its return of scale. Large agricultural leading enterprises interact with farmers by the Internet, guiding a wider range of learning behaviors, enhancing driving ability for farmers.

Value space has been expanded. In the process of creating the connection dividend between production and consumption, value from the internet cannot be compared with that of traditional industry. The value space is created while farmers meeting the individual needs of a certain type of consumer, it is much larger than the general production. Different types of consumer has different demand, the needs has heterogeneity, which brings value. The operation with contracted land in China is still in the majority, and it matches the market demand for personalized. Farmers' Professional Cooperatives, who are made of farmers, can organ their members to plant, meeting the market personalized demand, gaining a higher market premium, and sharing the premium to the inner members.

Cost has been reduced. The biggest advantage of the Internet is information symmetry. Symmetric information can reduce transaction costs, especially the search and supervision cost. Farmers can avoid fake and shoddy agricultural materials for agricultural products. The "Internet +" changes large agricultural machinery using mode for rent, and a "share" of agricultural machinery, etc. Farmers are more leasing of agricultural machinery, thereby reducing cost of agricultural machinery specialized assets such as sunk costs, also decreasing interest cost on capital. Big data, analysis of cloud computing, farmers and consumers gain more and accurate information, production and consumption can be effective coupling. The disintermediation in the Internet era, the wholesale market and agents, cannot create value, will be gradually abandoned by the Internet. At the same time few eragents mean less cost.

The "Internet +agriculture" is improving farmers' household income. In reality to promote "Internet + ", still need to perfect rural Internet facilities, support the corresponding talents, especially interdisciplinary talents who know both agriculture and the Internet, increase publicity, build "Internet + agriculture" atmosphere in rural society, guide farmers to establish "Internet +agriculture" consciousness, etc.

\section{References}

1. Li Haijian, Tian Yuexin (2014) Internet thinking and traditional enterprise reengineering. China Industrial Economy 10: 135-146.

2. Li Wenlian, Xia Yong (2013) Business model innovation based on "big data". China Industrial Economy 5: 83-95.

3. McAfe, Andrew, Erik Brynjolfsson (2012) Big Data: The Management Revolution. Harvard Business Review 10: 60-69.

4. Zhao Zhen (2015) Cross-border business of "Internet+" from the perspective of creative destruction. Chinese Industrial Economy 10: 146-160.

5. Li Guoying (2015) China's modern agricultural industry chain and the deconstruction of business model under the background of "Internet +". Rural Economy 9: 30-33.

6. Zhou Zhenxing (2015) Development modes of "Internet+" and path of Realization. Jiangsu Rural Economic 10: 30-32.

7. Zhou Hongmei (2015) Thinking of promote the "Internet plus agriculture" in Shanghai. Shanghai Rural Economy 9: 19-22.

8. Wu Peiliang. Analysis on the path of developing modern agriculture and deepening rural reform in South of Jiangsu [DB/OL].

9. Brown Brad, Chui, Michael, Manyika, James (2011) Are You Ready for the Era of "Big Data". McKinsey Quarterly 4: 28-40.

10. Luo min, Li Liangyu (2015) The innovative of business model in the Internet Era: from the perspective of the value creation. China Industrial Economy 1: 95-107.

11. Ye Ming (2015) The dilemma and solving path of The Internet industry dominant market. Law and Business Studies 1: 31-38. 


\section{Your next submission with Juniper Publishers will reach you the below assets}

- Quality Editorial service

- Swift Peer Review

- Reprints availability

- E-prints Service

- Manuscript Podcast for convenient understanding

- Global attainment for your research

- Manuscript accessibility in different formats

( Pdf, E-pub, Full Text, Audio)

- Unceasing customer service

Track the below URL for one-step submission https://juniperpublishers.com/online-submission.php 